\author{
Muhammad Arshad \\ Assistant Professor, Deanship of e-Learning and Information Technology \\ Jazan University, Jazan, Kingdom of Saudi Arabia \\ msarshad@jazanu.edu.sa
}

\author{
Shakeel Ahmad \\ Lecturer, Deanship of e-Learning and Information Technology \\ Jazan University, Jazan, Kingdom of Saudi Arabia \\ shakeel@jazanu.edu.sa
}

Farhan Ahmad Siddiqui

Assistant Professor, Department of Computer Science

University of Karachi, Karachi, Pakistan

farhan@uok.edu.pk

\title{
SOCIAL MEDIA TECHNOLOGIES AND THEIR BENEFITS IN HIGHER EDUCATION INSTITUTIONS: A SURVEY OF JAZAN UNIVERSITY
}

\begin{abstract}
The Saudi Arabia Vision 2030 plan is, in fact, an endeavor to establish the Kingdom as one of the most advanced and developed countries of the world. An Innovative approach and strategies are the main objectives of the Vision 2030 for the development of the country. Academia is focusing on various methodologies, which will help in elevating the importance of Saudi Higher Education Institution (HEI) to international standards. Social Media Technologies (SMTs) has turned into a developing phenomenon by numerous and diverse classifications in community and educational practice. The term SMTs denotes to web-oriented and mobile based applications that enable peoples and societies to produce, involve, and share new applications or current content, in digital world through multi-path communication. The emergence of Social Media Technologies has enforced mentors to think differently about the way learning occurs. HEI are investigating the use of various domains of Social Media Technologies for pedagogical purposes. These domains comprise blogs for instructions, wikis for shared content creation and podcasting to record teaching materials and making videos. However, HEI of the Kingdom are lagging behind in the incorporation of SMTs in learning and teaching. This research aims to establish contemporary instructions, learning practices, attitudes and scope of SMTs in the HEI pedagogy. A case study has been carried out in Jazan University that involved a mixed method approach to explore the practice of Social Media Technologies in the educational process.
\end{abstract}

Keywords: e-Learning; social media technologies; collaborative learning methods; uses of social networking sites; knowledge management; benefits of social networking sites; new and emerging pedagogy; learning technologies for students.

\section{INTRODUCTION}

The Kingdom of Saudi Arabia was set up in 1932. A poor nation started its instructional platform with a few hundred students in less than 15 schools. These circumstances transformed dramatically after exploring for oil in a huge amount in 1938. Therefore, in just 12 years of hard work, the Kingdom of Saudi Arabia developed new educational institutions with more than 40,000 students. Later in 1954, the Ministry of Education was formed which incorporated all educational levels in Saudi Arabia [1].

\subsection{History of Saudi Arabian Higher Education and Internet}

The Kingdom of Saudi Arabia is the biggest nation on the Arabian Gulf. Most of the advanced education colleges and universities within the Kingdom rely on the national assets that originated from the oil eruption $[2,3]$.

However, the economy of the Kingdom has rapidly changed, and the management has built up novel procedures to expand the profitability of the economy. As an outcome of the 
new vision for the Kingdom, it has become more challenging to meet the nation's higher education requirements. Since the start of the year 2016, the crown prince Mohammed bin Salman has adopted an innovative vision and procedures for the enhancement of Saudi Arabia to become a first world country among the most exceptional nations on the planet by 2030 .

Therefore, the leaders of HEI have replied positively to the development of world-class universities and higher education. Generally, the significant difficulties facing Saudi educational institutions are research efficiency, recognition and enhancing quality [4, 5, and 6].

While the Internet has been formed into an essential tool in the telecommunications industry, Saudi Arabia introduced the Internet quite late to the general population as compared to established or emerging nations. This delay was due to the worries of the top administration about the impact of the Internet on traditional values and principles. Therefore, educational institutions were equipped with and introduced to the latest Internet technology before introducing it to the general public [7].

King Abdulaziz City for Science and Technology (KACST) set up an Internet Service Unit (ISU) by taking the responsibility to introduce Internet facilities accessible to everyone, besides securing the qualities and Muslim convictions of the local citizens. There was an outstanding boost in the usage of the Internet in Saudi Arabia from 1999 to 2001. Internet users increased dramatically from a hundred thousand to ten hundred thousand in just those two years. In early 2014, these figures reached to more than 16 million Internet users, which was $55.1 \%$ of the whole population of the Kingdom $[8,9]$. To better comprehend this great development, take a look at Figure 1 [8].

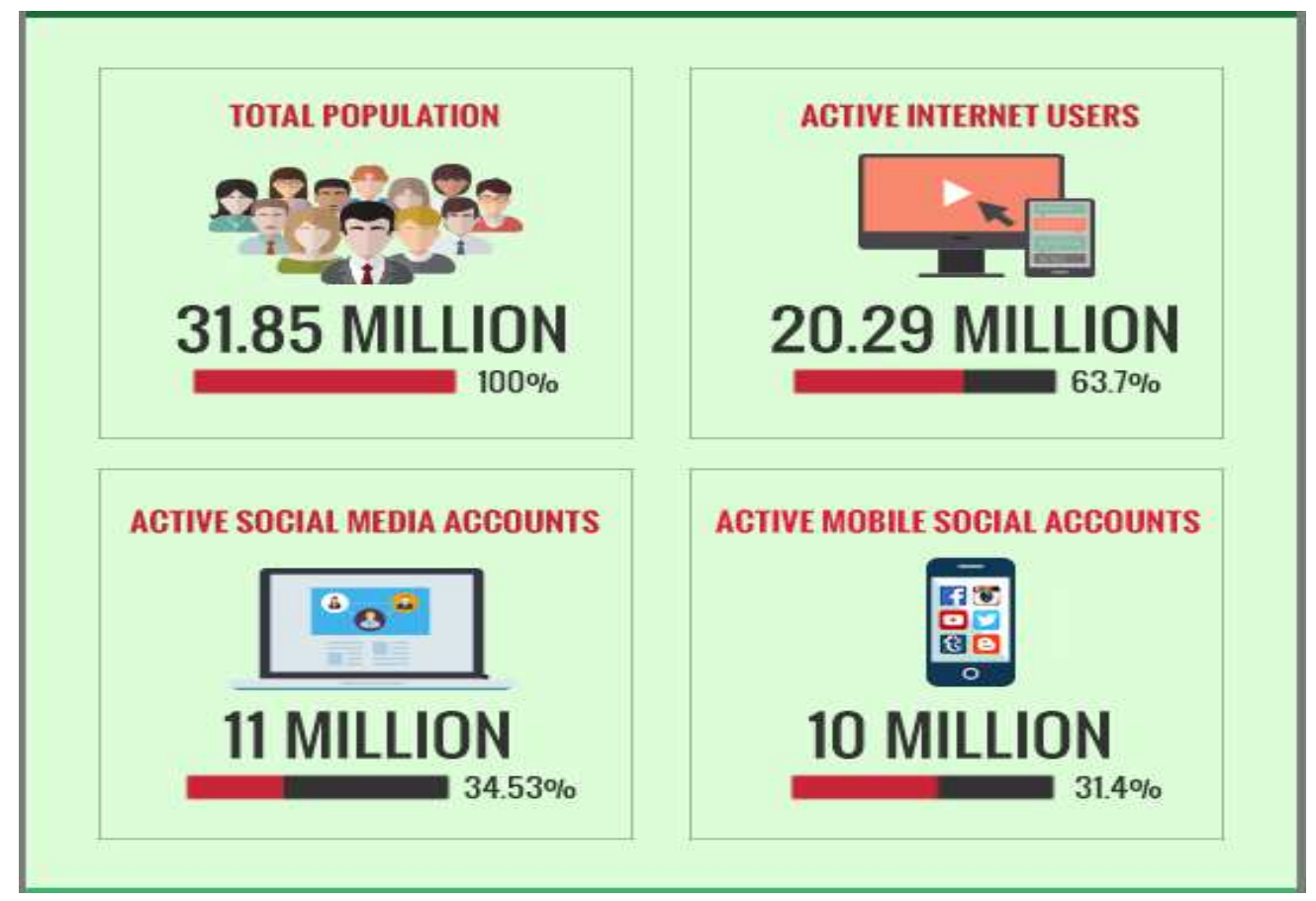

Figure 1. Social media statistics of Saudi Arabia [8]

Recently, there has been clear interest in the utilization of SMTs among higher education students and emphasis on creating $21^{\text {st }}$-century skills. Research discoveries have demonstrated that these students utilize around 94 percent of their time on SMTs during the whole week [9]. It is expected that the use of the Internet will continue to increase within the Kingdom, which will increase the requirement to equip the institutions with new learning 
techniques where the utilization of emerging technologies can be achieved in a productive way. All the institutions have free Internet accessibility, and with the help of this facility, teachers and other instructors can prepare the syllabus, tasks assignments, quizzes and literature reference to expedite the educational process. On the other hand, students are independent to access data online and concentrate on their studies freely [10, 11, 12 and 13].

This research funded project was led by the Deanship of e-Learning and Information Technology under the name "A Feasibility Study of a Collaborative e-Learning Environment through Social Media for Saudi Arabian Higher Educational Institutions". This project was granted under the $7^{\text {th }}$ Scientific Research Grant through the Ministry of Higher Education, Deanship of Scientific Research, Jazan University, Kingdom of Saudi Arabia. The foremost objective of this research project, especially this paper, has been to explore the importance and benefits of SMTs within Jazan University during teaching, learning and research by the help of the existing instructors' and students' frameworks, attitudes and prospects. This research work has utilized a blended technique to examine the utilization of SMTs, and the core outcomes have been discussed.

\section{LITERATURE REVIEW}

\subsection{Learning and e-Learning 2.0}

Learning describes two behaviors. Students are working together, sharing thoughts and finding the best solutions; secondly, students are connecting with other students all over the world on various topics of study [14]. It is the basic information that Social Media Technologies are utilizing basically for collaboration purposes. Learning is likewise seen as social action, where learners build their understanding through cooperation with the material, as well as through cooperatively developing new information with their colleagues [15].

The shift to Web 2.0 has its counterparts in both e-Learning technology and methodology, this pattern is known as e-Learning 2.0. The main objective of e-Learning 2.0 is cooperative learning that means an innovatively determined approach to exchange the information with students. One of the best techniques behind e-Learning 2.0 is connectivity, focusing on making associations (i.e., joining) among learning assets and individuals. eLearning 2.0 brings, additionally, robust emphasis on content syndication, its reuse/repurposing, adjustment and personalization [16 and 17].

\subsection{Electronic Social Networks (ESNs) and Corporate Social Networks (CESNs)}

Learning is a combination of Information and communication. Electronic Social Networks (ESNs) is an innovative learning method that is preferred by teachers around the globe in the educational process. Assessment, description, grouping, combination and application of formative assessment are the common methods of ESN. Nowadays, ESNs are very famous methods for setting up social connections and correspondence. The ESN correspondence is between teachers and students by social entities, e.g., photographs, acoustic messages, videos and presentation etc. Each of these entities can be a successful learning method in a specific systematic framework. An instructor utilizes a range of procedures (combined, separate and group) with students; the selection of the learning method is the most significant part [18].

The arrangement of articles and utilization of ESNs are helpful for educators and management to teach students in Corporate Social Networks (CESNs). The main modules of Corporate Social Networks (CESNs) are:

- Methods of learning style (combined, separate and group) 
- Techniques of learning (Forum, quizzes, discussions, video-conference lectures, virtual tours, article competitions, visual-stories etc.)

Social growth is joined by significant and continuously expanding parts of instruction that have challenges identified with the making up of a proper educational learning environment. As discussed earlier, social networks become more popular in an educational environment for communication medium. Researchers and scientists are still exploring the deployment of social networks in an efficient way for learning and teaching because these networks have exceptional possibilities for the socialization of students [19].

\subsection{Supporting Concept}

The inescapability and association of networking-based innovation have made a critical diversity in teaching and learning. The concept of learning has been changed especially in the "transmission of information from instructors to the students"; hence, students effectively take an interest in the development of learning. The supporting concept includes the theory of constructivism, socio-constructivism and media synchronicity [20].

\subsection{Social media technologies and Sites - Ideals for Education}

Social media technologies and sites have a direct impact on the daily Internet user. Utilizing and updating Twitter, YouTube, Facebook, LinkedIn, Pinterest and Spotify is today a part of everybody's second environment. Many clients see social media as an approach to associate and make companions, and as a significant advertising instrument. Others view time spent via social media sites as voyeurism, and more awful, an entire wastage of time as illustrated in Figure 2.

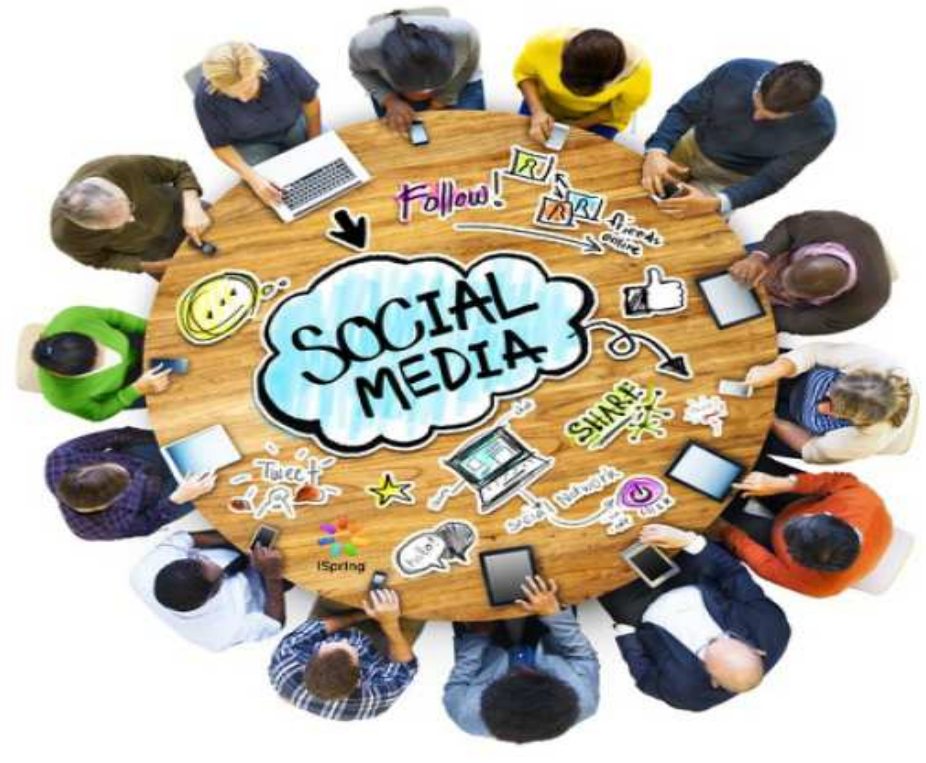

Figure 2. Social media technologies [19]

Though, nobody can deny the potential of social media technologies and sites in eLearning. A recent report by [21] demonstrates that SMTs expands the student's inspiration and comprehension. This research work further demonstrated that the increases were not subject to the students' computer abilities-empowering information for associations, hoping to teach a wide range of individuals and not for early birds only. Table 1 [22 and 23] describes the world-renowned social media technologies and sites with their description and learning techniques. 


\section{World-Renowned Social media technologies and Sites}

\begin{tabular}{|c|c|}
\hline Tools and sites & Description and learning techniques \\
\hline Podcasts & $\begin{array}{l}\text { - Excellent medium for distributing content. } \\
\text { - Working on computers and mobile devices. } \\
\text { - Particularly for audio learners, quick and easy to record. } \\
\text { - Help and learning topics are easily available. }\end{array}$ \\
\hline Facebook & $\begin{array}{l}\text { - Group discussion is much easier for instructors. } \\
\text { - Sharing information, pictures, videos, questionnaires etc. } \\
\text { - Students are able to freely talk with the instructor. }\end{array}$ \\
\hline Webinars & $\begin{array}{l}\text { - Face-to-face collaborations over documents, presentations, audio, video, sharing } \\
\text { screen, drawing tools and chats. } \\
\text { - } \text { Replays are available from archives for later learning. }\end{array}$ \\
\hline $\begin{array}{l}\text { Google } \\
\text { Collaboration } \\
\text { Tools }\end{array}$ & $\begin{array}{l}\text { - This tool contains videos, presentations, team website creation, word processing, } \\
\text { spreadsheets, conversations, emails, IM and photo sharing and more. } \\
\text { - These are all available via a web browser; authenticated user can easily generate } \\
\text { content, share knowledge and drop off feedbacks. }\end{array}$ \\
\hline Twitter & $\begin{array}{l}\text { - Particular topic or event connected by learning groups or classroom. } \\
\text { - Sharing pictures, videos, and updates. } \\
\text { - } \text { \#hashtag used for microblogging and communicating with individuals. }\end{array}$ \\
\hline YouTube & $\begin{array}{l}\text { - Exceptional resources for e-Learning. } \\
\text { - Educators can easily broadcast their lectures and tutorials free of cost. } \\
\text { - Students can watch these lectures and make suggestions and comments. }\end{array}$ \\
\hline Twiducate & $\begin{array}{l}\text { - Known as a "Walled Garden". } \\
\text { - Free and authenticated site for teachers and students to work together. } \\
\text { - Simply manageable by class code instead of email address. } \\
\text { - Teacher has full control to monitor member's activities. }\end{array}$ \\
\hline Blackboard & $\begin{array}{l}\text { - Industry leader in course management systems. } \\
\text { - This tool is an incredibly powerful, secure and wide-ranging platform. } \\
\text { - Training tutorials are available for new teachers. } \\
\text { - Very expensive platform, but provides quality and flexibility. }\end{array}$ \\
\hline Skype & $\begin{array}{l}\text { - Extraordinary potential tool for educators. } \\
\text { - Easily bring the outside world right into your classroom. } \\
\text { - Manage the classroom as an authors, visit science lab or talk to pen pals from around } \\
\text { the world. }\end{array}$ \\
\hline
\end{tabular}

\section{RESEARCH METHODOLOGY}

The authors have used a blended technique to collect the data by the help of a literature review, questionnaires and discussion with experts. This technique gave the authors an opportunity to analyze this research work from different points of view which has helped to innovate a multidimensional set of results.

After a detailed literature review, which had been collected from well-known and wellorganized resources like books, websites, articles and journals, online surveys were conducted. The audiences were full-time faculty members of Jazan University from different departments who had been involved in academic activities for the last five to eight years. In these surveys, the authors investigated the thoughts and opinions of teachers regarding SMTs' importance and utilization in teaching, especially for e-Learning students of Jazan University.

Lastly, questionnaires were designed for the online survey forms; these survey forms were: 
- Devices used by Teachers

- Social Media Technology benefits in HEI

- Forthcoming plan to practice Social Media

- Teacher recommendation for upcoming use of SMTs in education

- Expertise established by SMTs

The authors used a questionnaire instrument (Google Forms) to design the online questionnaire survey which was sent to participating faculty members of various departments at Jazan University. Online questionnaires were sent to 60 faculty members of different departments of Jazan University, where 56 responses were returned which were confined and useful. All of the questionnaires were used to analyze the perception of the teachers towards the practice of SMTs in academic activities by the help of existing frameworks, attitudes and prospects.

\section{RESULTS AND DISCUSSION}

\subsection{Numerical Analysis of the Questionnaire}

Figure 3 categorizes the participants from the different departments. Online Google Forms were sent to 60 faculty members of Jazan University from various departments. They were the members of e-Learning and Information Technology department, followed by Computer Science, then Computer Networks and finally by Information Systems departments.

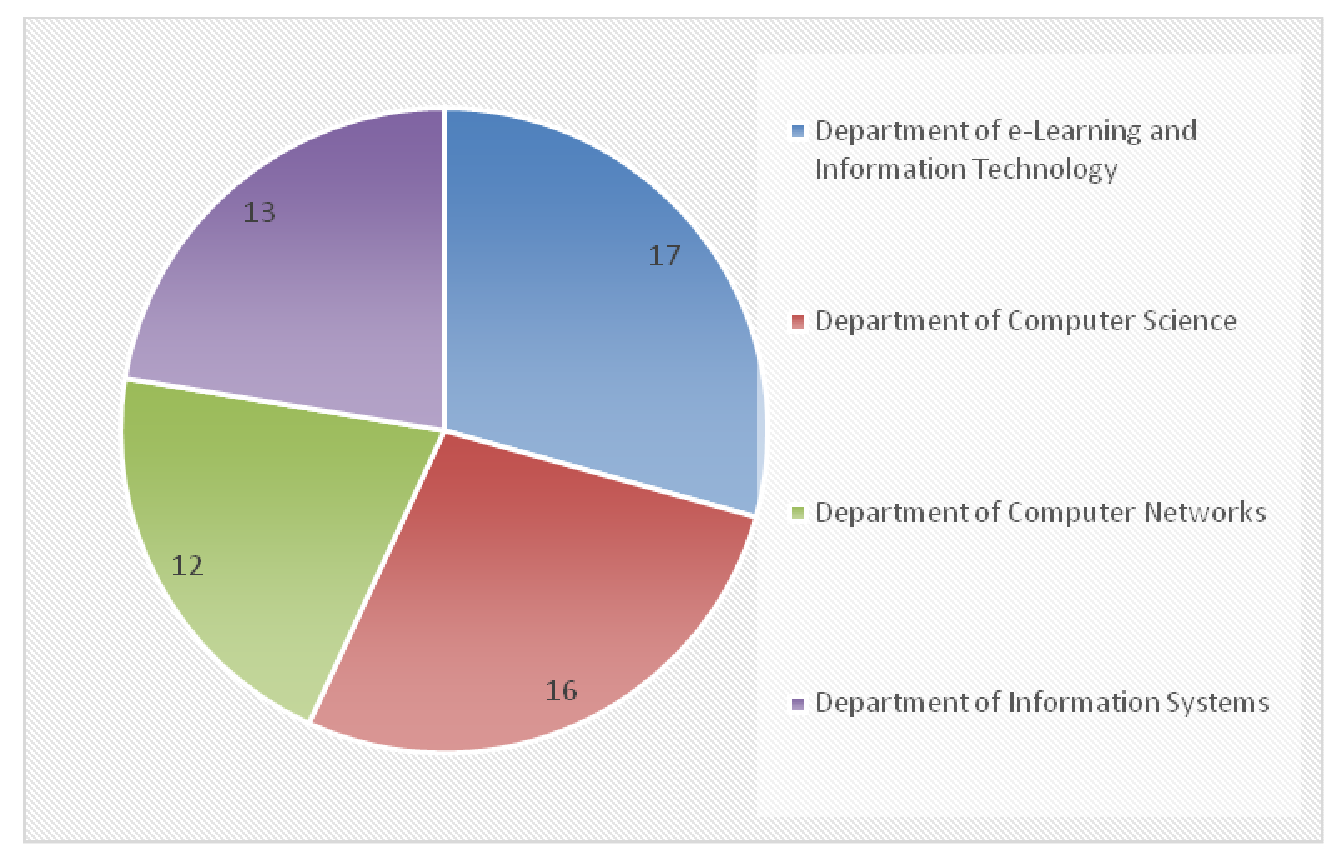

Figure 3. Participants from Departments

Figure 4 demonstrates the devices used by teachers, which are connected by the Internet. From this figure it is clear that most of the teachers used laptops, $67.8 \%$ with Internet access. The other devices, which were used but not heavily with Internet connection, were smartphones used by $16.3 \%$, desktops used by $10.7 \%$, and Tablets and iPads used by $3.5 \%$ and $1.7 \%$, respectively. 


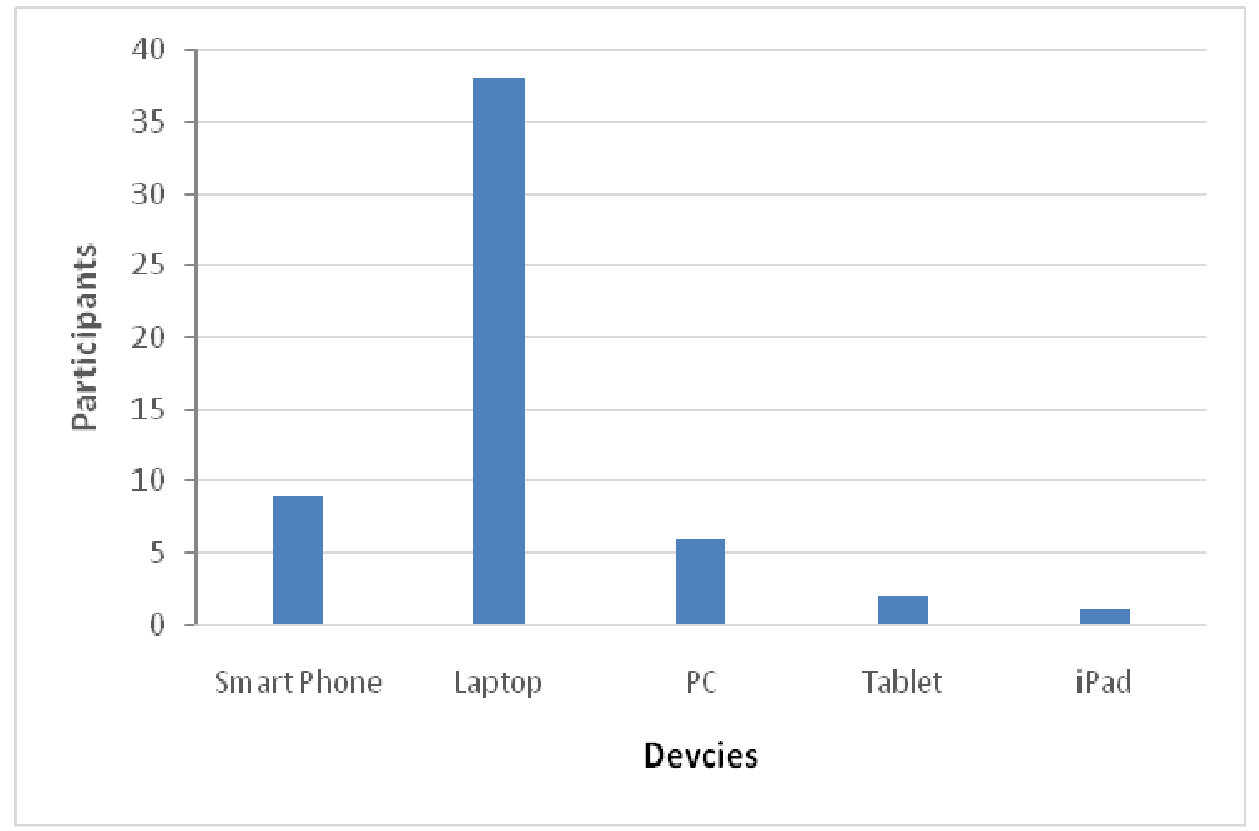

Figure 4. Devices used by teachers

The advantages of utilizing SMTs during academic learning and research activities are shown (56 out of the 60 faculty members) in Figure 5. According to faculty members SMTs could make it more comfortable to discover data, serving as wide sources of information, easy in access, saving time and globally available.

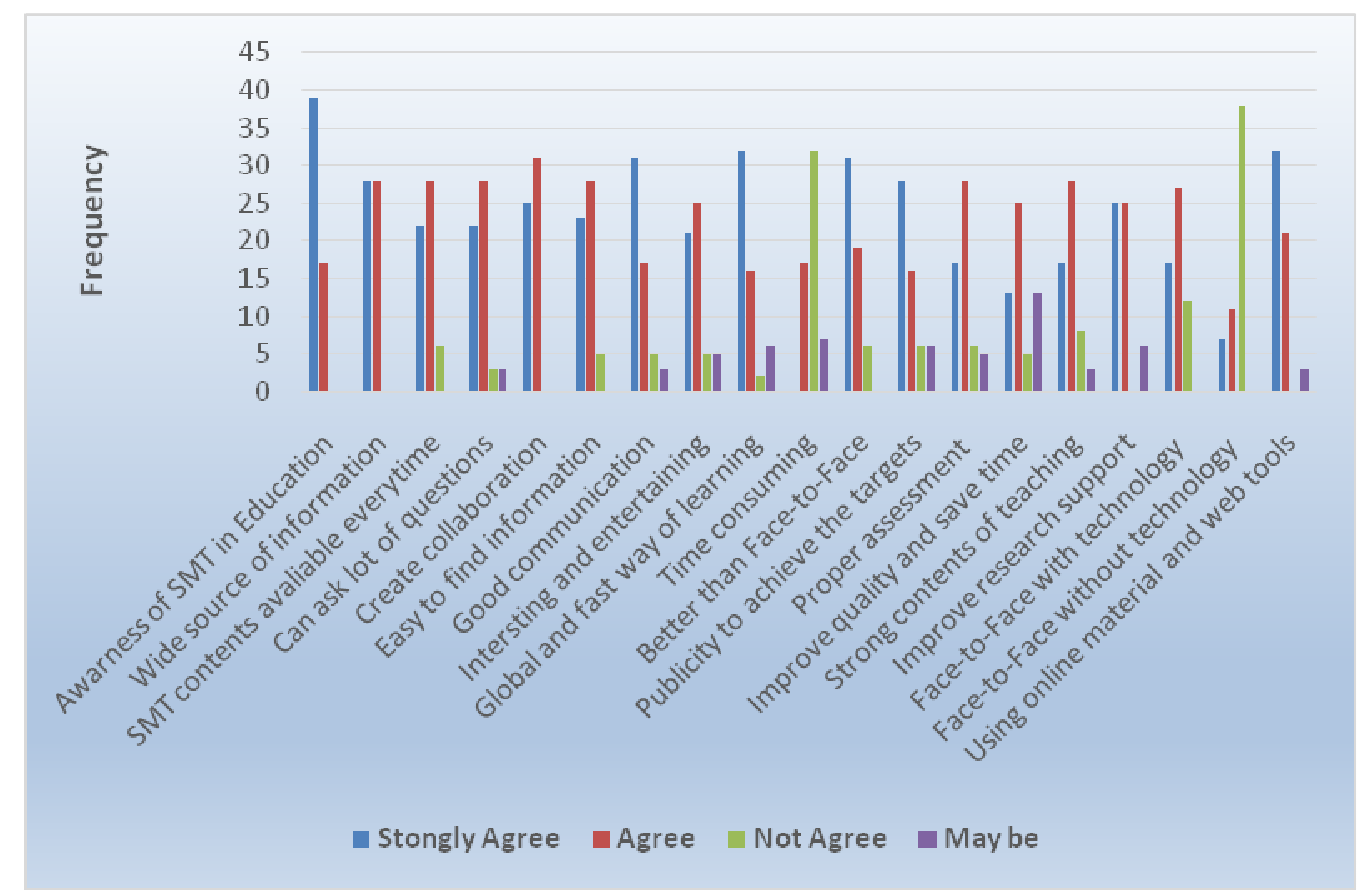

Figure 5. Social media technology benefits in HEI

A greater number of the respondents, 56 out of the 60 faculty members, demonstrating $93.3 \%$, plan to use Social Media in learning and research in the near future, as shown in Figure 6. Some of these faculty members are already using SMTs and are well aware of the 
new innovations, for example, Facebook, YouTube, Twitter and Chats, as they communicate with loved ones.

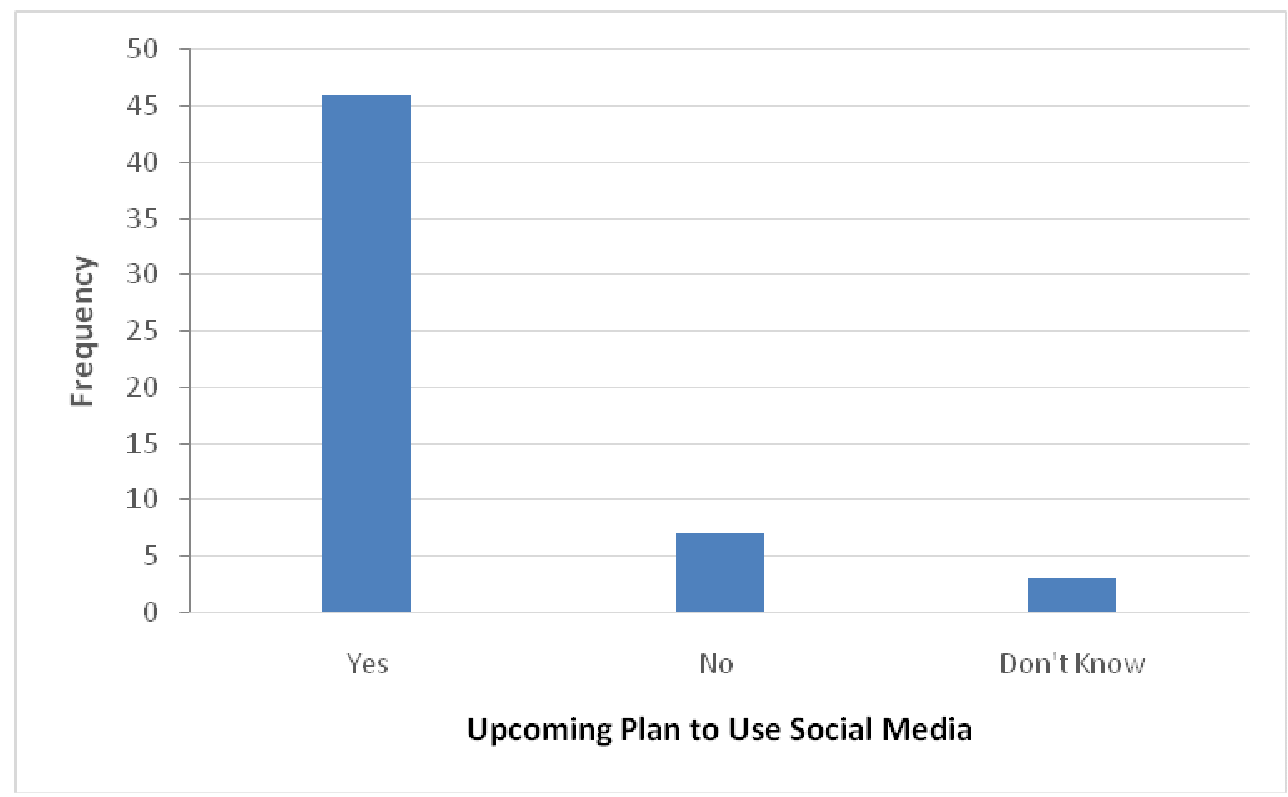

Figure 6. Forthcoming plan to practice social media

The teacher's recommendations for upcoming use of SMTs during learning, research and teaching are illustrated in Figure 7. It is clear that most of the teachers use Facebook (92.8\%), YouTube (98.1\%), Skype (87.5\%) and LMS (76.7\%).

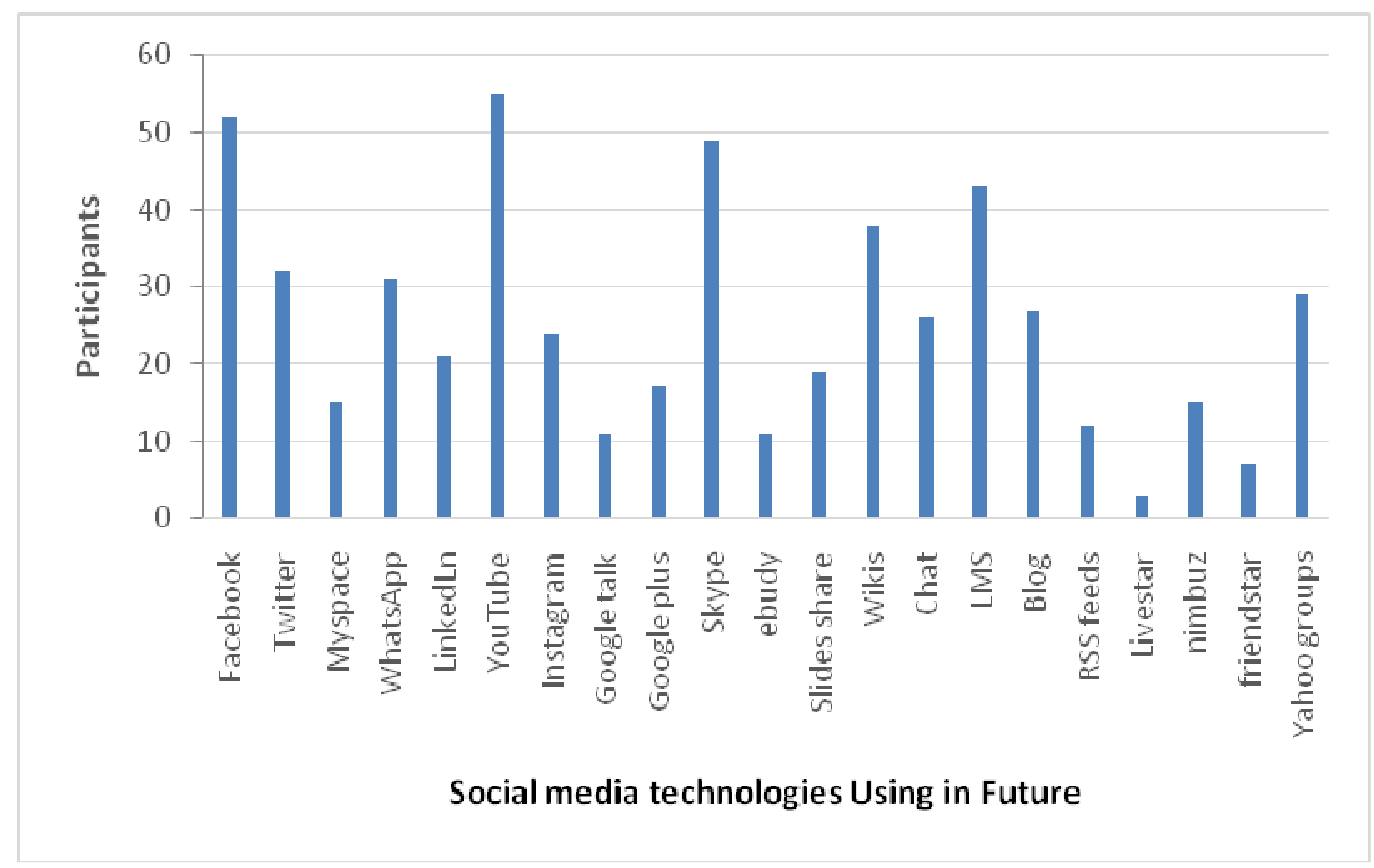

Figure 7. Upcoming use of SMTs in education

The above figure also illustrates that the social media technologies which are not being used extensively comprise WhatsApp (55.3\%), LinkedIn (37.5\%) and Blog (48.2\%). The 
different applications which appear to guarantee incorporation are Twitter, Slide share, Yahoo groups and google plus.

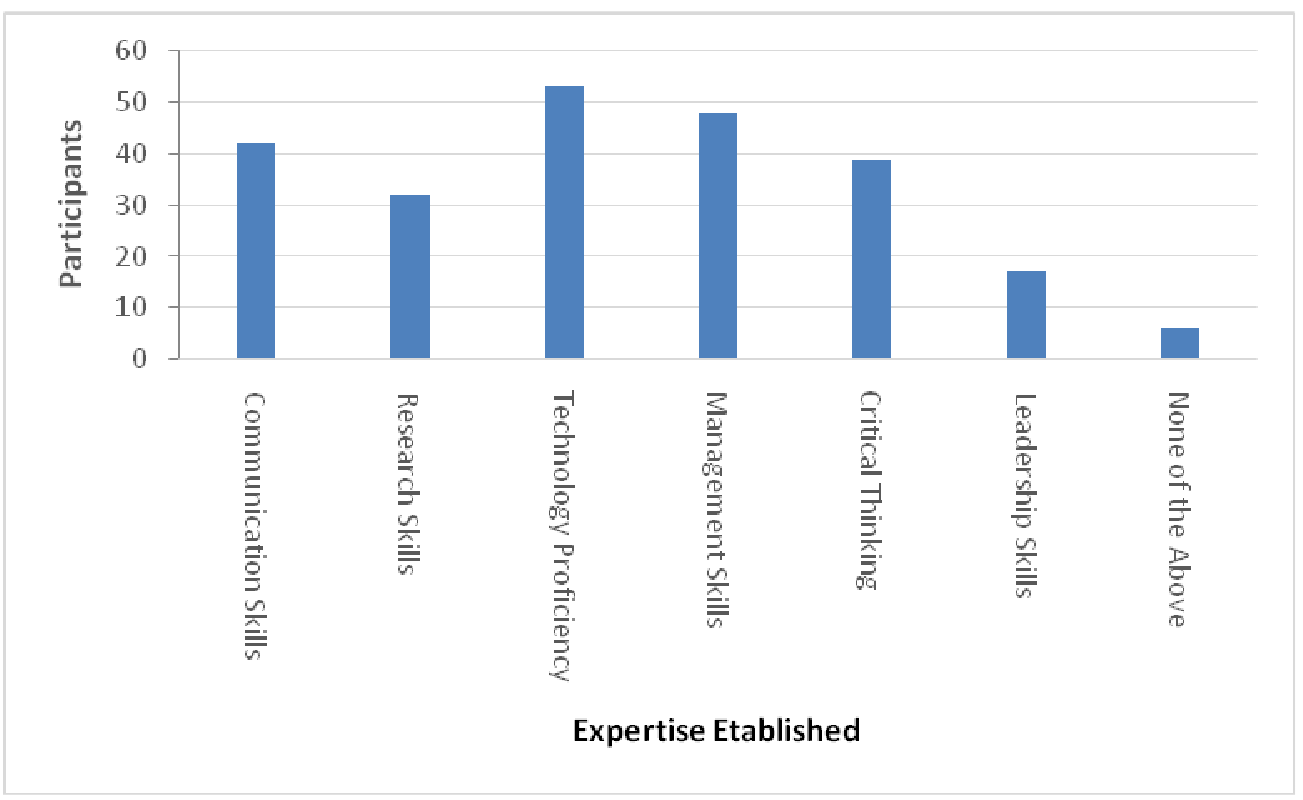

Figure 8. Expertise established by using SMTs

Concerning the abilities gained by teachers through the utilization of SMTs, it was discovered that the maximum $(92.8 \%)$ of the teachers gained technology proficiency because of utilizing social media technologies. This was followed by management skills and communication skills. A small percentage of the teachers $(10 \%)$ demonstrated that they did not increase any abilities with the assistance of SMTs; these statistics have been indicated in Figure 8.

\section{CONCLUSIONS AND FUTURE WORK}

The advanced education framework in Saudi Arabia has to take extraordinary actions for settling the difficulties, where higher education has to fulfill the requirements and the dream of The Crown Prince for the nation. Leaders in higher education have to take big steps to enhance the educational demands by raising their performances with the best quality results in the upcoming years.

Social Media advancements are useful instruments when included in training and education, and in this recent era, there is no doubt that higher educational institutions are grasping this notion. The combination of SMTs in the educational process is named as eLearning 2.0. This survey was conducted at Jazan University and distributed in different departments. The information developed has given a few highlighted features as to how teaching staff has been utilizing SMTs for individual, group and formal education. Most of the teaching staff responded positively to the combination of SMTs in education and learning.

The conclusion of this research work is to achieve benefits like technology proficiency, communication and management skills etc. by the implementation of SMT in Saudi Arabian HEI. This research is significant to the world of knowledge and Saudi Arabian Higher Educational System particularly for e-Learning and its related fields that also support the involvement of SMTs in the educational process. 
In future work the authors will do further examinations and expansion of aspects that have an impact on cooperative and group-oriented studies. This additional research work will also focus on how to enhance student's academic efficiency and presentation, consider statistic elements and have more illustrations to clear up and uncover components to quantify the elements that influence a student's educational accomplishment through supportive learning in higher educational institutions.

\section{ACKNOWLEDGEMENT}

This research work received funding under the Seventh Research Grant Scheme, which is sponsored by Deanship of Scientific Research, Jazan University, Jazan, Kingdom of Saudi Arabia.

\section{REFERENCES}

1. M. Alamri, "Higher Education in Saudi Arabia," Journal of Higher Education Theory and Practice vol. 11(4) 2011.

2. Eman Abdulrahman Radi Alharbi, "Higher Education in Saudi Arabia: Challenges to Achieving WorldClass Recognition, "International of Journal of Culture and History, Vol. 2(4): 169 -172, December 2016.

3. A. Hamdan, "A. Hamdan, "An exploration into" private" higher education in Saudi Arabia: Improving quality and accessibility? The ACPET Journal for Private Higher Education, vol. 2, no. 2, 2013.

4. K. T . Hilal, "Between the fears and hopes for a different future for the nation-states: Scholarship programs in Saudi Arabia and United Arab Emirates from a public policy standpoint," IJHE International Journal of Higher Education, vol. 2, no. 2, 2013.

5. A. Al-Musallam, "Higher education accreditation and Quality Assurance in the Kingdom of Saudi Arabia," presented at the First National Conference for Quality in Higher Education, Riyadh, Saudi Arabia, 2009.

6. M. Abdulhalem and P. G. Altbach, "Dreams and realities: The world-class idea and Saudi Arabian higher education," Higher Education in Saudi Arabia Achievements, Challenges and Opportunities, Springer Netherlands, pp. 1571-0378, 2013.

7. Hamed A. Alshahrani, “A Brief History of the Internet in Saudi Arabia," Springer Link, vol. 60(1), pp. 19-20, January 2016 .

8. Gmi-blogger, "Saudi Arabia Social Media Statistics 2016," [online]. Available at http://www.globalmediainsight.com/blog/saudi-arabia-social-media- statistics/.

9. Higher Education Research Institute, "College freshmen and online social networking sites," 2007, [online]. Available:http://www.gseis.ucla.edu/heri/PDFs/pubs/briefs/brief-091107-SocialNetworking.pdf. Retrieved June 1, 2012.

10. Al-Tawil, K. (2001). The Internet in Saudi Arabia. Telecommunications Policy, 25(8), $625-634$. doi:10.1016/S0308-5961(01)00036-2.

11. Chanchary, F. H., \& Islam, S., "Mobile learning in Saudi Arabia-prospects and challenges," Paper presented at the international Arab conference on information technology (ACIT'2011). Jordan: Zarqa University.

12. Communications and Information Technology Commission (CITC) (2014). Annual report 2014. [online]. Available: http://www.citc.gov. sa/english/Pages/default.aspx

13. Ministry of Communications and Information Technology (MOCIT) (2003). Information and telecommunication technology in Saudi Arabia (Report No. WSIS/PC-3/CONTR/25-E), World Summit on the information society, Geneva.

14. E. Klopfer, S. Osterweil, J. Groff and J Haas, "The Instructional Power of Digital Games, Social Networking and Simulations and How Teachers Can Leverage Them," Boston: The Education Arcade, 2009.

15. Ngonidzashe Zanamwe, Taurai Rupere and Owen Kufandirimbwa,'Use of Social Networking Technologies in Higher Education in Zimbabwe: A learners' perspective," International Journal of Computer and Information Technology (ISSN: 2279 - 0764) Volume 02- Issue 01, January 2013

16. Pavel Drasil, Tomas Pitner, "E-Learning 2.0: Methdology, Technology and Solutions," [online]. Available: http://www.fi.muni.cz/ tomp/12/e-Learning2.0/icte/12_platform.pdf 
17. Downes, S. E-Learning 2.0, ACM eLearn Magazine, 2006, [online]. Available: URL:http://www.elearnmag.org/subpage.cfm?section=articles\&article=29-1. [cit. 2006-06- 18].

18. Lytvynova, S. H. and Pinchuk, O. P., "The Evolution of Teaching Methods of Students in Electronic Social Networks", Proceedings of the 13th International Conference on ICT in Education, Research and Industrial Applications. Integration, Harmonization and Knowledge Transfer (1844). pp. 360-371.

19. S. Lytvynova, and O. Burov, "Methods, Forms and Safety of Learning in Corporate Social Networks", in Proc. of the 13th Inter. Conf. on ICT in Education, Research and Industrial Applications. Integration, Harmonization and Knowledge Transfer, Kyiv, Ukraine, 2017, pp. 406-413

20. P. C. Rogers, S. W. Liddle, P. Chan, A. Doxey, and A. Isom, "A Web 2.0 learning platform: Harnessing collective intelligence," Turkish Online Journal of Distance Education (TOJDE), vol. 8, pp. 16-33, 2007.

21. M. Rossafri, "The Effectiveness of Social Networking Applications in e-Learning," in Education Management, Education Theory and Education Application, Springer Berlin Heidelberg, 2012, pp. 79-85.

22. iSpring, providing quality software that everyone loves to use. [online]. Available: https://www.ispringsolutions.com/blog/10-social-media-tools-ideal-for-e-learning/

23. TeachThought is a brand dedicated to innovation in K-20 education. [online]. Available:https://www.teachthought.com/technology/10-different-social-media-sites-for-education/

24. P. Drášil and T. Pitner, "E-LEARNING 2.0: METHODOLOGY, TECHNOLOGY AND SOLUTIONS," in ICTE 2006, International Conference on Information and Communication Technology in Education, 2006.

\title{
СОЦІАЛЬНІ МЕДІА-ТЕХНОЛОГІЇ ТА ПЕРЕВАГИ ЇХ ВИКОРИСТАННЯ У ЗАКЛАДАХ ВИЩОЇ ОСВІТИ: ДОСЛІДЖЕННЯ ДЖАЗАНСЬКОГО УНІВЕРСИТЕТУ
}

\author{
Мохамед Аршад \\ доцент, кафедра електронного навчання та інформаційних технологій \\ Джазанський Університет, місто Джазан, Королівство Саудівська Аравія \\ msarshad@jazanu.edu.sa

\begin{abstract}
Шакіл Ахмад
викладач, кафедра електронного навчання та інформаційних технологій Джазанський Університет, місто Джазан, Королівство Саудівська Аравія shakeel@jazanu.edu.sa
\end{abstract}

Фархан Ахмад Сіддікі

доцент, кафедра комп'ютерних наук

Університет Карачі, місто Карачі, Пакистан

farhan@uok.edu.pk

\begin{abstract}
Анотація. План розвитку Саудівської Аравії до 2030 - це, фактично, прагнення зробити Королівство однією з передових і найбільш розвинутих держав світу. Інноваційний підхід і стратегії визначено основними цілями Стратегічного розвитку країни 2030 (Vision 2030). Академія зосереджує увагу на різних методологіях, які сприятимуть підвищенню статусу вищих навчальних закладів (ВН3) Саудівської Аравії та їх наближенню до міжнародних стандартів. Соціальні медіа-технології (СМТ) перетворилися на феномен, що активно розвивається, має різноманітні класифікації, які використовуються у суспільстві та навчальній практиці. Термін СМТ означає веб-орієнтовані та мобільні додатки, які дозволяють людям і соціальним спільнотам створювати, залучати та ділитися новими програмами або вже існуючим контентом у цифровому світі через багато каналів комунікації. Поява соціальних медіа-технологій змусила менторів по-різному думати про те, як саме відбувається навчальний процес. Вищі навчальні заклади досліджують особливості використання різних галузей соціальних медіа-технологій з метою навчання. До них відносять: блоги для надання вказівок, вікі для створення спільного контенту та підкасти для записування навчальних матеріалів і створення різних відеозаписів. Проте ВНЗ Королівства значно відстають щодо впровадження СМТ у навчальний процес. Дане дослідження спрямоване на визначення сучасних інструкцій, методів навчання, установок і сфер застосування СМТ у системі вищої освіти. У Джазанському університеті було
\end{abstract}


проведено тематичне дослідження, із застосуванням змішаного підходу, з метою вивчення практичного використання соціальних медіа-технологій у навчальному процесі.

Ключові слова: електронне навчання; соціальні медіа-технології; спільні методи навчання; використання сайтів соціальних мереж; управління знаннями; переваги соціальних мереж; нова педагогіка і педагогіка, що розвивається; технології навчання студентів.

\title{
СОЦИАЛЬНЫЕ МЕДИА-ТЕХНОЛОГИИ И ПРЕИМУЩЕСТВА ИХ ИСПОЛЬЗОВАНИЯ В ВЫСШИХ УЧЕБНЫХ ЗАВЕДЕНИЯХ: ИССЛЕДОВАНИЕ ДЖАЗАНСКОГО УНИВЕРСИТЕТА
}

\author{
Мохаммед Аршад \\ доцент \\ кафедра электронного обучения и информационных технологий \\ Университет Джазана, город Джазан, Королевство Саудовская Аравия \\ msarshad@jazanu.edu.sa \\ Шакил Ахмад \\ преподаватель \\ кафедра электронного обучения и информационных технологий \\ Университет Джазана, город Джазан, Королевство Саудовская Аравия \\ shakeel@jazanu.edu.sa
}

\author{
Фархан Ахмад Сиддики \\ доцент \\ кафедра компьютерных наук \\ Университет Карачи, город Карачи, Пакистан \\ farhan@uok.edu.pk
}

\begin{abstract}
Аннотация. План развития Саудовской Аравии до 2030 года - это, в сущности, стремление превратить Королевство в одно из самых передовых и развитых государств мира. Главными целями Концепции 2030 для развития страны являются инновационный подход и стратегии. Академия уделяет основное внимание различным методологиям, которые помогут повысить значение Саудовских учреждений высшего образования (ВУЗов) и привести их к международным стандартам. Технологии социальных медиа (ТСМ) превратились в развивающееся явление благодаря многочисленным и разнообразным классификациям в сообществах и образовательной практике. Термин ТСМ обозначает веб-ориентированные и мобильные приложения, которые позволяют людям и обществам создавать, привлекать и делиться новыми приложениями или ранее созданным контентом в цифровом мире при помощи многоканальной коммуникации. Появление социальных медиа-технологий заставило менторов по-другому осмыслять особенности учебного процесса. ВУЗы изучают способы использования разных аспектов социальных медиа-технологий для образовательных целей. К ним относятся блоги для инструкций, вики для создания общего контента и подкасты для записывания учебных материалов, и создания видео. Однако ВУЗы Королевства отстают в вопросе внедрения ТСМ в учебно-образовательный процесс. Данное исследование направлено на проецирование инструкций, современных методик обучения, установок и сферы применения ТСМ в ВУЗах. В Джазанском университете было проведено тематическое исследование, в котором для изучения вопросов практического использования социальных медиа-технологий в учебном процессе, использовался смешанный метод.
\end{abstract}

Ключевые слова: электронное обучение; социальные медиа-технологии; совместные методы обучения; использование сайтов социальных сетей; управление знаниями; преимущества сайтов социальных сетей; новая и развивающаяся педагогика; технологии обучения студентов.

\section{$(\mathrm{Cc}) \mathrm{EY-NC-SA}$}

This work is licensed under Creative Commons Attribution-NonCommercial-ShareAlike 4.0 International License. 